\title{
Tolvaptan reduces the required amount of albumin infusion in patients with decompensated cirrhosis with uncontrolled ascites : a multicenter retrospective propensity score-matched cohort study
}

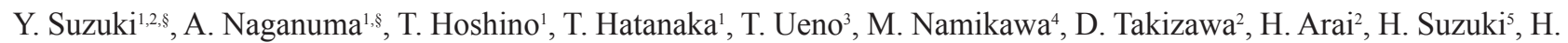 \\ Takagi $^{6}$, H. Tojima, Y. Yamazaki ${ }^{7}$, K. Sato ${ }^{7}$, S. Kakizaki ${ }^{7}$, T. Uraoka \\ (1) Department of Gastroenterology, National Hospital Organization Takasaki General Medical Center, 36 Takamatsu-cho, Takasaki, Gunma 370-0829, Japan ; (2) \\ Department of Gastroenterology, Maebashi Red Cross Hospital, Maebashi, Gunma 371-0014, Japan ; (3) Department of Internal Medicine, Isesaki Municipal Hospital, \\ Isesaki, Gunma 372-0817, Japan ; (4) Department of Internal Medicine, Kiryu Kosei General Hospital, Kiryu, Gunma 376-0024, Japan ; (5) Department of Internal \\ Medicine, Haramachi Red Cross Hospital, Higashiagatsuma, Gunma 377-0882, Japan ; (6) Department of Gastroenterology, Kusunoki Hospital, Fujioka, Gunma 375-0024, \\ Japan ; (7) Department of Gastroenterology and Hepatology, Gunma University Graduate School of Medicine, 3-39-22 Showa-machi, Maebashi, Gunma 371-8511, Japan.
}

\begin{abstract}
Background: The aim of this retrospective study was to determine whether tolvaptan treatment reduces the amount of albumin administered, volume of ascites removed, and frequency of paracentesis procedures in patients with decompensated cirrhosis with uncontrolled ascites with conventional diuretics.

Patients and methods : The control (C) group included patients treated with conventional diuretics. The tolvaptan $(T)$ group included patients treated with both tolvaptan and conventional diuretics. Both groups were matched according to baseline parameters. The amount of albumin administered, volume of ascites removed, and frequency of paracentesis within $\mathbf{3 0}$ days of onset of uncontrolled ascites were compared between the two groups.

Results : After matching, 74 patients $(C=37, T=37)$ were included. Baseline parameters (C vs. $\mathrm{T}$ group) were as follows : age, $69.5 \pm 9.3$ vs. $70.4 \pm 11.0$ years $(p=0.702)$; males, $24(64.9 \%)$ vs. $25(67.6 \%)(p=0.999)$; patients with hepatocellular carcinoma, $17(45.9 \%)$ vs. $18(48.6 \%)(p=0.999)$; serum albumin levels at treatment initiation, $2.76 \pm 0.48$ vs. $2.73 \pm 0.49 \mathrm{~g} / \mathrm{dL}(\mathrm{p}=0.773)$ and serum creatinine levels at treatment initiation, $1.18 \pm 1.23$ vs. $1.09 \pm 0.48 \mathrm{~g} / \mathrm{dL}(\mathrm{p}=\mathbf{0 . 6 7 9})$. In the $\mathrm{C}$ vs. $\mathrm{T}$ groups, respectively, mean amount of albumin administered was $51.0 \pm 31.4$ vs. $33.4 \pm$ $29.8 \mathrm{~g} /$ month $(\mathrm{p}=\mathbf{0 . 0 1 6})$; mean volume of ascites removed was $2,905 \pm 4,921$ vs. $1,824 \pm 3,185 \mathrm{~mL} /$ month $(p=0.266)$; and mean frequency of paracentesis was $0.92 \pm 1.46 \mathrm{vs.} 0.89 \pm 1.45$ procedures $(p=0.937)$.

Conclusions : Tolvaptan reduced the use of albumin infusion in patients with decompensated cirrhosis and was effective and acceptable for uncontrolled ascites. (Acta gastroenterol. belg., 2021, 84, 57-63).
\end{abstract}

Keywords : albumin infusion, cirrhosis, paracentesis, uncontrolled ascites, tolvaptan.

\section{Introduction}

Ascites is the most frequent complication in patients with cirrhosis and is associated with poor prognosis. Management of ascites is based on a low-sodium diet and conventional diuretic therapies (loop diuretics and/ or potassium-sparing diuretics), although intravenous albumin infusion and large-volume paracentesis (LVP) have been used in cirrhosis patients with difficult-tocontrol refractory ascites (1). Since its approval in September 2013, tolvaptan has been used in Japanese hospitals to treat cirrhosis patients with ascites who were unresponsive to conventional diuretic therapies (2-4).
Tolvaptan is a unique diuretic agent, as it is a nonpeptide, arginine vasopressin V2-receptor antagonist administered orally (5-7). Recently, several studies reported the efficacy and safety of tolvaptan $(4,8,9)$, while others identified predictive factors for the therapeutic effects of tolvaptan (9-15). Furthermore, several studies reported that treatment of refractory ascites with tolvaptan may improve prognosis in patients with decompensated cirrhosis (16-18). However, whether tolvaptan contributes to reduction of albumin infusion amount and frequency of LVP remains unclear. Additionally, there are few reports that compare cirrhosis patients with refractory ascites before tolvaptan was approved with similar patients treated with tolvaptan (19). Therefore, the aim of this retrospective, multicenter collaborative study was to determine whether tolvaptan contributes to reduction of the amount of albumin administered, volume of ascites removed, and frequency of paracentesis.

\section{Patients and methods}

\section{Study design}

Clinical data were retrospectively collected from the electronic medical records of cirrhosis patients with uncontrolled ascites with conventional diuretics from a multi-institutional, joint study of seven hospitals during the period from January 2016 to March 2017. The final follow-up date was April 30, 2017.

\section{Inclusion and exclusion criteria}

We enrolled liver cirrhosis patients (over 20 years old) with uncontrolled ascites who had received loop diuretic and/or antialdosterone agents for at least

\footnotetext{
Correspondence to: Atsushi Naganuma, M.D., Ph.D., Department of Gastroenterology, National Hospital Organization Takasaki General Medical Center, 36 Takamatsu-cho, Takasaki, Gunma 370-0829, Japan. Telephone : +8127-322-5901. Fax : +81-27-322-6111

E-mail : naganuma2000@gmail.com

${ }^{\S}$ These authors contributed equally to this work.

Submission date : 09/12/2019

Acceptance date : 09/07/2020
} 
7 days. In this study, the definition of uncontrolled ascites with conventional diuretics differed from that of refractory ascites per European Association for the Study of the Liver/American Association for the Study of Liver Diseases (EASL/AASLD) clinical practice guidelines (20,21). Uncontrolled ascites was defined as the presence of new-onset ascites with poor response to therapy (treatment with a loop diuretic at a daily dose equivalent to $\geq 20 \mathrm{mg} /$ day furosemide and/or $\geq 25 \mathrm{mg} /$ day spironolactone) detected by ultrasound. This original definition of uncontrolled ascites was based on the eligibility criteria adopted in a phase 3 study from Japan conducted to validate the therapeutic effects of tolvaptan on hepatic edema associated with liver cirrhosis (2). The onset of uncontrolled ascites was defined as the condition whereby paracentesis (ascites drainage $\geq 1$ L) was required for the first time to reduce pain from abdominal distension. Patients were required to be hospitalized or available for hospitalization during the treatment period. Exclusion criteria were the presence of uncontrolled hepatic encephalopathy, hepatocellular carcinoma (HCC) with major portal vein tumor thrombus, inability to take oral medication, or end-stage renal disease on hemodialysis. Even patients with West Haven criteria (WHC) $(22,23)$ grade II or higher uncontrolled hepatic encephalopathy because of use of conventional diuretics were allowed entry if hepatic encephalopathy could be controlled to WHC grade I or lower for over 1 month with nonabsorbable disaccharides, antibiotics (i.e., rifaximin), or branched-chain amino acid supplementation.

\section{Patient characteristics and treatment methods}

Thirty-seven patients treated with conventional diuretic therapies (loop diuretics and/or potassiumsparing diuretics) and albumin infusion or paracentesis between January 2010 and August 2013 were enrolled as the control (C) group. This cohort marks the time period before tolvaptan was approved for treatment of cirrhosis with uncontrolled ascites in Japan (September 2013).

In our clinic, unlike EASL/AASLD clinical practice guidelines, albumin infusion was generally administered to maintain circulating plasma volume when serum albumin level was less than $3.5 \mathrm{~g} / \mathrm{dL}$, or over $3 \mathrm{~L}$ of ascites were drained.

The tolvaptan (T) group included 138 patients treated with tolvaptan in addition to conventional diuretics between September 2013 and June 2015. Tolvaptan was used in addition to conventional diuretics and was introduced at $3.75 \mathrm{mg} /$ day in most cases $(24,25)$. If there was no weight loss after about 1 week, the dose of tolvaptan was increased to $7.5 \mathrm{mg}$ /day and continued for over 1 month. In total, 131 patients in the $\mathrm{T}$ group were used for analysis of patient baseline parameters (five cases with major portal vein tumor thrombus and two cases that could not be followed up were excluded). To reduce potential bias resulting from differences in baseline parameters between the $\mathrm{C}$ and $\mathrm{T}$ groups, propensity score (PS) matching was applied for patients with new-onset refractory ascites that became difficult to control with conventional diuretics after January 2010. After PS matching, the mean amount of $25 \%$ albumin infusion administered, mean volume of ascites removed, and mean frequency of LVP within 30 days of refractory ascites were evaluated in both groups. In the T group, refractory ascites treatment was considered effective when weight loss of $\geq 2 \mathrm{~kg}$ was observed within 2 weeks of the tolvaptan administration start date.

\section{Propensity score matching}

To reduce treatment-selection bias and potential confounding variables between the $\mathrm{C}$ and $\mathrm{T}$ groups, we performed rigorous adjustment for marked differences in baseline patient characteristics with PS matching using the following algorithm : 1:1 optimal match with a \pm 0.036 caliper and no replacement. Possible confounders were selected based on clinical knowledge for their potential association with the outcome of interest. The PS model was estimated using a logistic regression model that adjusted for patient characteristics such as sex, age, serum albumin level, serum creatinine level, presence of HCC, and Child-Pugh score at baseline. To measure covariate balance, an absolute standardized difference above $10 \%$ represented meaningful imbalance $(26,27)$.

\section{Safety assessment}

Patients were monitored during the study period, and any occurrence of adverse events were noted retrospectively. To confirm the adverse effects of conventional therapy and tolvaptan, changes in laboratory data and state of hepatic encephalopathy were evaluated before and 4 weeks after conventional therapy and introduction of tolvaptan. Safety assessment was performed in 37 patients for whom we were able to collect data 4 weeks after the start of conventional treatment in the $\mathrm{C}$ group, and was performed in 100 patients for whom we were able to collect data 4 weeks after the start of tolvaptan in the T group. Adverse events were evaluated using the Common Terminology Criteria for Adverse Events, version 5.0 (CTCAE v5.0) (28).

\section{Statistical analyses}

Regarding baseline parameters, categorical data were compared using Fisher's exact test, while continuous data were compared using an unpaired t-test. The total amount of albumin infusion, volume of ascites removed, and frequency of paracentesis in the two groups were also compared using an unpaired t-test. For safety assessment, adverse events were compared using Fisher's exact test. A p-value $<0.05$ was considered statistically significant. All analyses were performed using SPSS version 25.0 software (SPSS Inc, Chicago, IL, USA). 


\section{Results}

\section{Baseline parameters of patients}

Between January 2010 and June 2015, a total of 175 patients were retrospectively enrolled from seven hospitals (Figure 1). Based on the exclusion criteria, we compared baseline parameters in 37 (C group) and 131 ( $\mathrm{T}$ group) patients before PS matching (Table 1). Baseline parameters (C vs. T group) were as follows : mean age, $69.5 \pm 9.1$ vs. $68.4 \pm 11.0$ years ; males, $24(64.9 \%)$ vs. 76 patients $(58 \%)$; presence of HCC, 17 (45.9\%) vs. 54 $(41.2 \%)$; etiologies, hepatitis B : 1 vs. 15 , hepatitis C : 34 vs. 60 , alcohol use : 2 vs. 31 , others : 0 vs. 25 ; ChildPugh class, A : 3 vs. 2 , B : 24 vs. 60 , C : 10 vs. 69 . Child-
Pugh class $\mathrm{C}$ was significantly more frequent in the $\mathrm{T}$ group than in the $\mathrm{C}$ group $(\mathrm{p}=0.006)$. Mean laboratory data ( $\mathrm{C}$ vs. $\mathrm{T}$ group) at treatment initiation were as follows : serum albumin levels were $2.76 \pm 0.48$ vs. 2.49 $\pm 0.47 \mathrm{~g} / \mathrm{dL}(\mathrm{p}=0.002)$; serum total bilirubin levels were $1.89 \pm 0.90$ vs. $2.67 \pm 3.64 \mathrm{mg} / \mathrm{dL}(\mathrm{p}=0.614)$; blood urea nitrogen levels were $23.7 \pm 15.5$ vs. $26.4 \pm$ $15.1 \mathrm{mg} / \mathrm{dL}(\mathrm{p}=0.220)$; serum creatinine levels were $1.18 \pm 1.22$ vs. $1.08 \pm 0.48 \mathrm{mg} / \mathrm{dL}(\mathrm{p}=0.580) ;$ serum sodium levels were $135.3 \pm 7.2$ vs. $136.1 \pm 5.0 \mathrm{mEq} / \mathrm{L}$ (p $=0.650)$; and serum ammonia levels were $68.7 \pm 46.7$ vs. $67.9 \pm 38.0 \mathrm{~g} / \mathrm{dL}(\mathrm{p}=0.960)$. Serum albumin levels at baseline were significantly lower in the $\mathrm{T}$ group than in the $\mathrm{C}$ group. Renal function did not differ significantly between the groups. In both groups, the combination

Table 1 Baseline parameters of patients in both groups before propensity score matching

\begin{tabular}{|c|c|c|c|}
\hline Parameter & Control group & Tolvaptan group & $P$ value \\
\hline Number of patients & 37 & 131 & \\
\hline Sex (male, \%) & $24(64.9)$ & $76(58.0)$ & 0.570 \\
\hline Age (years) & $\begin{array}{c}69.5 \pm 9.3 \\
(69,47-84)\end{array}$ & $\begin{array}{l}68.4 \pm 11.0 \\
(70,38-90)\end{array}$ & 0.604 \\
\hline $\begin{array}{l}\text { Child-Pugh class (A/B/C) } \\
\text { HCC (\%) }\end{array}$ & $\begin{array}{l}3 / 24 / 10 \\
17(45.9)\end{array}$ & $\begin{array}{c}2 / 60 / 69 \\
54(41.2)\end{array}$ & $\begin{array}{l}0.006 \\
0.745\end{array}$ \\
\hline Etiology & & & \\
\hline HBV/HCV/Alcohol use/others & $1 / 34 / 2 / 0$ & $15 / 60 / 31 / 25$ & 0.200 \\
\hline Serum albumin (g/dL) & $\begin{array}{c}2.76 \pm 0.48 \\
(2.8,1.4-4.0)\end{array}$ & $\begin{array}{c}2.49 \pm 0.47 \\
(2.5,1.1-4.0)\end{array}$ & 0.002 \\
\hline Serum total bilinubin (mg/mL) & $\begin{array}{c}1.89 \pm 0.91 \\
(1.80,0.40-5.10)\end{array}$ & $\begin{array}{c}2.67 \pm 3.64 \\
(1.54,0.20-21.00)\end{array}$ & 0.614 \\
\hline Serum blood urea nitrogen (mg/dL) & $\begin{array}{l}23.8 \pm 15.7 \\
(20,5.0-83.0)\end{array}$ & $\begin{array}{c}26.4 \pm 15.1 \\
(23,4.0-75.0)\end{array}$ & 0.220 \\
\hline Serum creatinine ( $\mathrm{mg} / \mathrm{dL})$ & $\begin{array}{c}1.18 \pm 1.23 \\
(0.90,0.33-8.00)\end{array}$ & $\begin{array}{c}1.08 \pm 0.48 \\
(0.91,0.35-3.11)\end{array}$ & 0.580 \\
\hline Serum sodium (mmol/L) & $\begin{array}{c}135.4 \pm 7.2 \\
(136,99-144)\end{array}$ & $\begin{array}{c}136.1 \pm 5.0 \\
(137,118-145)\end{array}$ & 0.650 \\
\hline Serum ammonia (mg/dL) & $\begin{array}{c}71.4 \pm 46.5 \\
(63,12.0-212.0)\end{array}$ & $\begin{array}{c}67.9 \pm 38.0 \\
(59,5.0-218.0)\end{array}$ & 0.960 \\
\hline Combination diuretics & & & \\
\hline furosemide (mg/day) & $\begin{array}{c}31.7 \pm 20.4 \\
(20.0,0-80.0)\end{array}$ & $\begin{array}{c}34.3 \pm 18.0 \\
(40.0,0-100.0)\end{array}$ & 0.261 \\
\hline spironolactone (mg/day) & $\begin{array}{c}40.3 \pm 16.4 \\
(50,12.5-75)\end{array}$ & $\begin{array}{c}40.1 \pm 18.3 \\
(31.25,0-100.0)\end{array}$ & 0.496 \\
\hline
\end{tabular}

HCC: hepatocellular carcinoma; HBV: hepatitis B virus; HCV: hepatitis C virus. Data are presented as mean \pm standard deviation. Median and range are shown in parentheses. Unpaired ttest was used to compane the median values of each variable between the two groups. Categorical data were compared using Fisher's exact test.

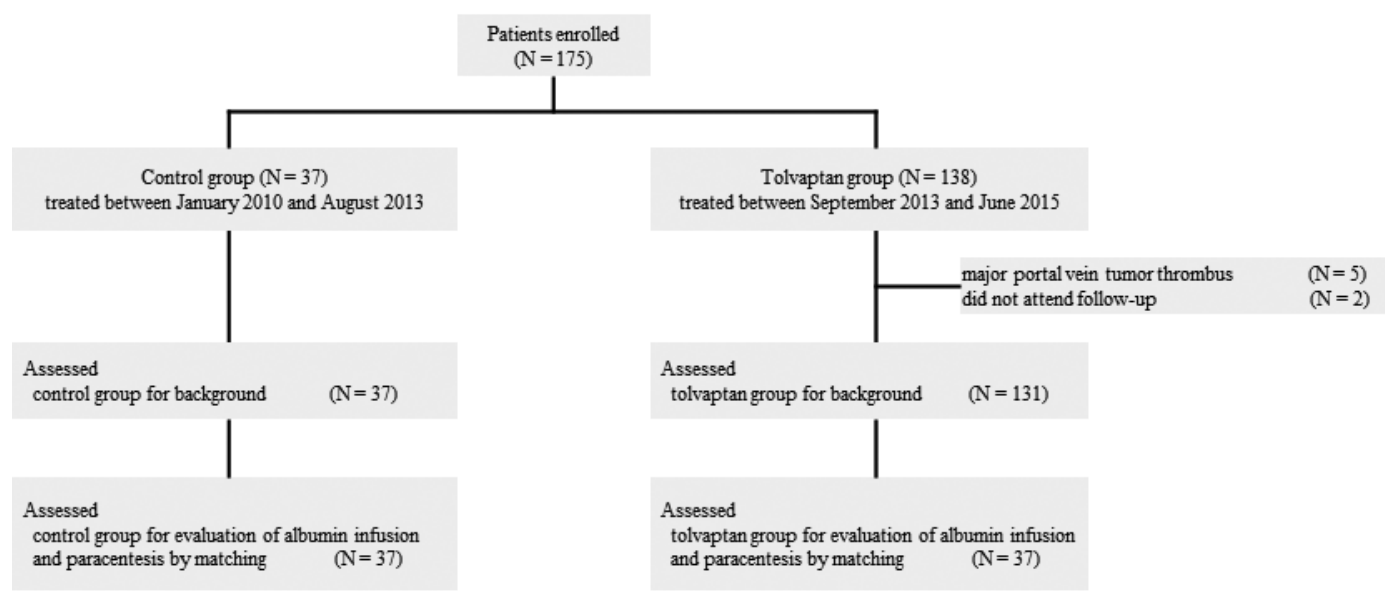

Figure 1. - Flowchart of enrolled patients 
Table 2 Baseline parameters of patients in both groups after propensity score matching

\begin{tabular}{lccc}
\hline \multicolumn{1}{c}{ Parameter } & Control group & Tolvaptan group & $P$ value \\
\hline Number of patients & 37 & 37 & \\
Sex (male, \%) & $24(64.9)$ & $25(67.6)$ & 0.999 \\
Agg (years) & $69.5 \pm 9.3$ & $70.4 \pm 11.0$ & 0.702 \\
& $(69,47-84)$ & $(70,38-90)$ & \\
Child-Pugh class (A/B/C) & $3 / 24 / 10$ & $2 / 22 / 13$ & 0.451 \\
HCC (\%) & $17(45.9)$ & $18(48.6)$ & 0.999 \\
Etiology & $1 / 34 / 2 / 0$ & $2 / 20 / 6 / 9$ & 0.999 \\
HBV/HCV/Alcohol use/others & $2.76 \pm 0.48$ & $2.73 \pm 0.49$ & 0.773 \\
Serum albumin (g/dL) & $(2.8,1.4-4.0)$ & $(2.5,1.1-4.0)$ & \\
& $1.89 \pm 0.91$ & $2.00 \pm 1.77$ & 0.737 \\
Serum total bilinubin (mg/mL) & $(1.80,0.40-5.10)$ & $(1.47,0.30-8.20)$ & \\
& $23.8 \pm 15.7$ & $27.1 \pm 14.8$ & 0.350 \\
Serum blood urea nitrogen (mg/dL) & $(20,5.0-83.0)$ & $(23,8.0-68.0)$ & \\
& $1.18 \pm 1.23$ & $1.09 \pm 0.48$ & 0.679 \\
Serum creatinine (mg/dL) & $(0.90,0.33-8.00)$ & $(0.91,0.35-3.11)$ & \\
& $135.4 \pm 7.2$ & $136.4 \pm 5.1$ & 0.511 \\
Serum sodium (mmol/L) & $(136,99-144)$ & $(138,118-145)$ & \\
& $71.4 \pm 46.5$ & $71.8 \pm 32.0$ & 0.979 \\
Serum ammonia (mg/dL) & $(63,12.0-212.0)$ & $(70,28.0-137.0)$ & \\
Combination diuretics & $31.7 \pm 20.4$ & $35.0 \pm 20.9$ & 0.502 \\
furosemide (mg/day) & $(20.0,0-80.0)$ & $(40.0,0-100.0)$ & \\
& $40.3 \pm 16.4$ & $37.9 \pm 22.3$ & 0.640 \\
spironolactone (mg/day) & $(50,12.5-75)$ & $(43.8,0-100.0)$ & \\
& & & \\
& & &
\end{tabular}

HCC: hepatocellular carcinoma; HBV: hepatitis B virus, HCV: hepatitis C virus. Data are presented as mean \pm standard deviation. Median and range are shown in parentheses. Unpaired t-test was used to compare the median values of each variable between the two groups. Categorical data were compared using Fisher's exact test.

Table 3 Grade 3 or worse adverse events (safety population)

\begin{tabular}{|c|c|c|c|c|c|}
\hline \multirow[b]{2}{*}{ Event } & \multicolumn{2}{|c|}{ Control group $(\mathrm{N}=37)$} & \multicolumn{2}{|c|}{ Tolvaptan group $(\mathrm{N}=100)$} & \multirow[t]{2}{*}{$P$ value } \\
\hline & No. & $\%$ & No. & $\%$ & \\
\hline Hypoalbuminemia & 3 & 8.1 & 7 & 7 & 1.000 \\
\hline Increased blood bilinubin & 1 & 2.7 & 14 & 14 & 0.069 \\
\hline Increased creatinine & 1 & 2.7 & 6 & 6 & 0.674 \\
\hline Hypematremia & 0 & 0 & 0 & 0 & 1.000 \\
\hline Hepatic encephalopathy & 3 & 8.1 & 12 & 12 & 0.759 \\
\hline Variceal bleeding & 1 & 2.7 & 2 & 2 & 1.000 \\
\hline Spontaneous bacterial peritonitis & 1 & 2.7 & 1 & 1 & 0.469 \\
\hline Hepatorenal syndrome & 0 & 0 & 2 & 2 & 1.000 \\
\hline Acute kidney injury & 0 & 0 & 1 & 1 & 1.000 \\
\hline
\end{tabular}

Safety assessment was performed in 37 cases in the control group and in 100 cases in the tolvaptan group, where data after 4 weeks were available. All adverse events were assessed according to the Common Terminology Criteria for Adverse Events (version 5.0).

The nomal ranges for each parameter in our hospitals were as follows; serum albumin 4.1-5.1 g/dL, serum total bilirubin 0.4-1.5 mg/dL, serum creatinine $0.65-1.07 \mathrm{mg} / \mathrm{dL}$ (male) and 0.46-0.79 mg/dL (female), serum sodium 138-145 mmol/L.

Grade 3/4 hypoalbuminemia indicates serum albumin level was less than 2 g/dL. Grade 3/4 increased blood bilinubin and increased creatine indicates the level of each was greater than $3 \mathrm{mg} / \mathrm{dL}$. Grade $3 / 4$ hyponatremia indicates symptomatic hyponatremia with sodium level of less than 130 mmol/L or sodium level of less than $125 \mathrm{mmol} / \mathrm{L}$

Fisher's exact test was used to compare the adverse events of each variable between the two groups.

of conventional diuretic therapies (loop diuretics and/ or potassium-sparing diuretics) was compared. Average use of furosemide was slightly lower in the $\mathrm{C}$ group than in the $\mathrm{T}$ group, but there was no significant difference (Table 1).

Patient characteristics after propensity score matching

Following PS matching, 37 patients from each group were further analyzed (Figure 1). Before matching, the T group had significantly more frequent Child-Pugh class
$\mathrm{C}$ and lower serum albumin levels than the $\mathrm{C}$ group. As shown in Table 2, no significant differences were observed between the $\mathrm{C}$ and $\mathrm{T}$ groups regarding baseline parameters after matching.

Comparison of amount of albumin infusion administered, volume of ascites removed, and frequency of paracentesis

After PS matching, the amount of $25 \%$ albumin infusion administered, volume of ascites removed, and frequency of paracentesis within 30 days of refractory 

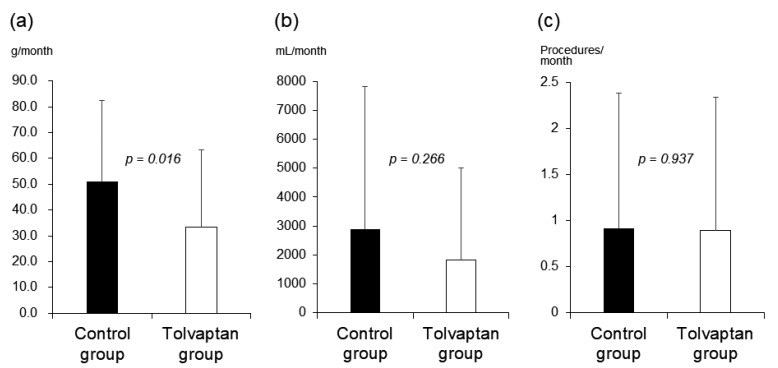

Figure 2. - Effects of tolvaptan on the dose of intravenous albumin infusion, volume of ascites removed, and frequency of paracentesis procedures. (a) Mean amount of albumin administered was $51.0 \pm 31.4 \mathrm{~g} /$ month (control group) vs. 33.4 $\pm 29.8 \mathrm{~g} /$ month (tolvaptan group) (unpaired t-test, $\mathrm{p}=0.016$ ). Mean amount of albumin administered was significantly reduced in the tolvaptan group. (b) Mean volume of ascites removed was $2,905 \pm 4,921 \mathrm{~mL} / \mathrm{month}$ (control group) vs. $1,824 \pm 3,185 \mathrm{~mL} / \mathrm{month}$ (tolvaptan group) (unpaired t-test, $\mathrm{p}=0.266$ ). (c) Mean frequency of paracentesis procedures was $0.92 \pm 1.46$ procedures/month (control group) vs. $0.89 \pm$ 1.45 procedures/month (tolvaptan group) (unpaired t-test, $\mathrm{p}=$ 0.937). Error bars represent standard deviation.

ascites were evaluated in both the $\mathrm{C}$ and $\mathrm{T}$ groups $(\mathrm{n}=$ 37 each). The mean amount of albumin administered was $51.0 \pm 31.4$ (C group) vs. $33.4 \pm 29.8 \mathrm{~g} /$ month (T group) $(p=0.016)$ (Figure 2a). The required albumin infusion in the $\mathrm{T}$ group was significantly reduced. The mean volume of ascites removed was 2,905 $\pm 4,921$ (C group) vs. 1,824 $\pm 3,185 \mathrm{~mL} / \mathrm{month}$ (T group) $(\mathrm{p}=0.266)$ (Figure $2 \mathrm{~b})$. The mean volume of ascites removed was also reduced in the $\mathrm{T}$ group, but no significant difference was observed. The mean frequency of paracentesis procedures was $0.92 \pm$ 1.46 (C group) vs. $0.89 \pm 1.45$ procedures ( $\mathrm{T}$ group) $(\mathrm{p}=$ 0.937) (Figure 2c). The mean frequency of paracentesis procedures was not significantly different between the two groups.

\section{Assessment of tolvaptan efficacy}

Based on records from electronic medical charts, it was possible to analyze the therapeutic effects of tolvaptan in 95 cases in the $\mathrm{T}$ group. Treatment for uncontrolled ascites with conventional diuretics was considered effective when weight loss of $\geq 2 \mathrm{~kg}$ was observed within 2 weeks of tolvaptan introduction. Tolvaptan treatment was effective in $52 \mathrm{~T}$ group patients (55\%).

\section{Safety assessment}

Safety assessment was performed in 37 cases in the $\mathrm{C}$ group and 100 cases in the $\mathrm{T}$ group where data after 4 weeks were available. Main adverse events (hypoalbuminemia, increased blood bilirubin, increased creatinine, hypernatremia, and hepatic failure (coma)) were assessed according to the CTCAE v5.0 (Table 3). There were no significant differences in these adverse events before and 4 weeks after treatment introduction between the two groups. No cases showed hypernatremia above $150 \mathrm{mmol} / \mathrm{L}$.

\section{Discussion}

A previous meta-analysis reported there were no data to support the routine use of tolvaptan in cirrhosis because tolvaptan has a small beneficial effect on ascites and hyponatremia, but no effect on mortality, complications of cirrhosis, or renal failure (29). Presently, EASL/AASLD practice guidelines do not recommend tolvaptan for the treatment of refractory ascites $(20,21)$. However, a recent meta-analysis reported that tolvaptan may play an effective and safe role in symptomatic treatment of cirrhosis patients with ascites, especially in cases with refractory ascites who present insufficient response to conventional diuretics (30). Therefore, tolvaptan for treatment of refractory ascites may be added to EASL/AASLD practice guidelines in the future. The 2015 evidence-based clinical practice guidelines for liver cirrhosis recommend introducing tolvaptan to treat early-stage ascites, which is difficult to control with conventional diuretics (furosemide and/or spironolactone) (25). Early introduction of tolvaptan can prevent exacerbation of renal dysfunction by reducing the use of conventional diuretics $(25,31)$. Moreover, our results indicated that administration of tolvaptan could reduce the albumin infusion amount required to treat uncontrolled ascites, while uncontrolled ascites in the $\mathrm{C}$ group was difficult to treat if hypoalbuminemia was present. In the $\mathrm{C}$ group, the frequent administration of albumin infusion was believed to be necessitated by an effort to increase the therapeutic effect of conventional diuretics (furosemide and/or spironolactone) (32). Because tolvaptan has a therapeutic effect regardless of serum albumin level $(33,34)$, treatment generally does not require albumin infusion. Therefore, total albumin infusion may have decreased more in the $\mathrm{T}$ group than in the $\mathrm{C}$ group, despite the $\mathrm{T}$ group having low serum albumin prior to treatment. At the start of the study, the $\mathrm{T}$ group included patients who underwent paracentesis several times. Therefore, there were many patients who received tolvaptan treatment after considerable time had elapsed from the onset of uncontrolled ascites in the $\mathrm{T}$ group, compared with the $\mathrm{C}$ group. Serum albumin level at the start of the study was therefore believed to be lower in the $\mathrm{T}$ group than in the $\mathrm{C}$ group. Differences in serum albumin levels at the start of ascites therapy in both groups may have affected the control of ascites. It would have been desirable to compare the two groups by aligning baseline serum albumin levels. Therefore, we performed matching to eliminate bias because of differences in baseline parameters, and then compared the two groups in terms of albumin infusion amount and frequency of paracentesis procedures. As a result, we determined that albumin infusion was significantly more reduced in the $\mathrm{T}$ group than in the $\mathrm{C}$ group. Recently, Caraceni et al. reported that long-term human albumin administration prolonged overall survival and may act as a disease-modifying treatment in patients with decompensated cirrhosis and ascites (35). However, 
albumin preparations are valuable resources derived from donated blood and are generally very expensive to use. Therefore, consuming large amounts of albumin infusion is a major medical economic disadvantage. It must be administered with utmost care, especially considering healthcare economics and infection risks. Tolvaptan can reduce the required amount of albumin infusion, and it is economically useful in the management of uncontrolled ascites in patients with decompensated cirrhosis.

Ohki et al. reported that tolvaptan reduces the number of hospitalizations and frequency of paracentesis procedures in uncontrolled ascites patients (19), although information on whether tolvaptan contributes to quality of life in patients with decompensated cirrhosis remains limited. We investigated whether tolvaptan decreased the number of paracentesis procedures. However, there was no significant difference between the two groups. It is possible that we could not detect a significant difference because the number of patients in the control group was less than that in the report by Ohki et al. In addition, the study by Ohki et al. was from a single center, while ours was a multicenter study. Therefore, there may have been variations in the criteria for conducting paracentesis.

In Japan, several studies reported the use of tolvaptan to treat uncontrolled ascites with conventional diuretics, and the number of patients receiving tolvaptan has increased in many Japanese hospitals. Notably, individual patients with uncontrolled ascites have diverse pathologies. Therefore, tolvaptan may not have ideal therapeutic effects in all patients. Chishina et al. reported that serum blood urea nitrogen and serum creatinine were significantly higher in non-responders to tolvaptan, and that the diuretic effect of tolvaptan may decrease in patients with renal hypofunction (31). Similarly, in our study, tolvaptan tended to be less effective in patients with high creatinine levels. Tolvaptan controlled ascites in over $50 \%$ of patients in the present study, with few serious adverse events. Although hypernatremia is a known side effect of tolvaptan, no severe hypernatremia was observed in a previous Japanese clinical trial (2). In this trial, serum sodium concentration was significantly increased from baseline on the final dosing day in the $\mathrm{T}$ group (135.3 [standard deviation (SD), 4.5 ] to $136.5 \mathrm{mmol} / \mathrm{L}$ [SD, 4.4], $\mathrm{p}=0.0002$ ) without severe hypernatremia. Add-on therapy of tolvaptan to conventional diuretics is expected to adequately improve serum sodium concentration in liver cirrhosis patients. Tolvaptan may be beneficial for liver cirrhosis patients through overall improvement of uncontrolled ascites and improvement of serum sodium concentration. In September 2013, Japan was the first country in the world where tolvaptan was approved for treatment of fluid retention in cirrhosis. Compared with conventional diuretics, tolvaptan has different pharmacological actions and is a useful option for treatment of uncontrolled ascites.

This study had several limitations. The study design was retrospective. The $\mathrm{C}$ group had a small number of patients and the timing of tolvaptan introduction was subjectively decided by each physician. Therefore, the results must be interpreted in consideration of these biases. Future prospective observational studies with well-defined conditions should be conducted to obtain accurate conclusions.

In conclusion, to our knowledge, this is the first report demonstrating that tolvaptan reduces the albumin infusion amount required to treat cirrhosis patients with uncontrolled ascites. This observation is attributed predominantly to tolvaptan's robust diuretic effects. However, further large-scale studies are required to validate and expand upon these observations.

\section{Acknowledgements}

The authors would like to thank Ms. Tomoko Okada, Ms. Noriko Ozawa, Ms. Mariko Nudejima, and members of the Gunma Liver Study Group for their excellent assistance.

\section{Disclosure}

Satoru Kakizaki and Ken Sato received lecture fees from Otsuka Pharmaceutical Co., Ltd. Other authors report no conflict of interest. All procedures followed were in accordance with the ethical standards of the responsible committee on human experimentation (institutional and national) and with the 1964 Helsinki Declaration and later versions. The need for written informed consent was waived because of the retrospective nature of the study, although we provided enrolled patients with the opportunity to opt out via a website.

\section{Funding}

The authors report no funding for the present study.

\section{References}

1. GINES P, ARROYO V. Paracentesis in the management of cirrhotic ascites. J. Hepatol., 1993, 17 Supp1 2 : S14-8.

2. SAKAIDA I, KAWAZOE S, KAJIMURA K, SAITO T, OKUSE C, TAKAGUCHI K, OKADA M, OKITA K. Tolvaptan for improvement of hepatic edema: A phase 3, multicenter, randomized, double-blind, placebocontrolled trial. Hepatol. Res., 2014, 44 : 73-82.

3. SAKAIDA I. Tolvaptan for the treatment of liver cirrhosis oedema. Expert Rev. Gastroenterol. Hepatol., 2014, $8:$ 461-70.

4. ZHANG X, WANG SZ, ZHENG JF, ZHAO WM, LI P, FAN CL, LI B, DONG PL, LI L, DING HG. Clinical efficacy of tolvaptan for treatment of refractory ascites in liver cirrhosis patients. World J. Gastroenterol., 2014, 20 : 11400-5.

5. GHEORGHIADE M, NIAZI I, OUYANG J, CZERWIEC F, KAMBAYASHI J, ZAMPINO M, ORLANDI C. Vasopressin V2-receptor blockade with tolvaptan in patients with chronic heart failure: results from a double-blind, randomized trial. Circulation, 2003, $107: 2690-6$.

6. DECAUX G, SOUPART A, VASSART G. Non-peptide arginine-vasopressin antagonists : the vaptans. Lancet, 2008, $371:$ 1624-32.

7. GASSANOV N, SEMMO N, SEMMO M, NIA AM, FUHR U, ER F. Arginine vasopressin (AVP) and treatment with arginine vasopressin receptor antagonists (vaptans) in congestive heart failure, liver cirrhosis and syndrome of inappropriate antidiuretic hormone secretion (SIADH). Eur. J. Clin. Pharmacol., 2011, 67 : 333-46.

8. AKIYAMA S, IKEDA K, SEZAKI H, FUKUSHIMA T, SORIN Y, KAWAMURA Y, SAITOH S, HOSAKA T, AKUTA N, KOBAYASHI M, SUZUKI F, SUZUKI Y, ARASE Y, KUMADA H. Therapeutic effects of short- and intermediate-term tolvaptan administration for refractory ascites in patients with advanced liver cirrhosis. Hep. Res., 2015, 45 : 1062-70. 
9. KOGISO T, TOKUSHIGE K, HASHIMOTO E, IKARASHI Y, KODAMA K, TANIAI M, TORII N, SHIRATORI K. Safety and efficacy of long-term tolvaptan therapy for decompensated liver cirrhosis. Hep. Res., 2016, 46 : E194-200.

10. SAKAIDA I, TERAI S, KUROSAKI M, YASUDA M, OKADA M, BANDO K, FUKUTA Y. Effectiveness and safety of tolvaptan in liver cirrhosis patients with edema: Interim results of post-marketing surveillance of tolvaptan in liver cirrhosis (START study). Hep. Res., 2017, 47 : 1137-46.

11. KAWARATANI H, FUKUI H, MORIYA K, NOGUCHI R, NAMISAKI T, UEJIMA M, KITADE M, TAKEDA K, OKURA Y, KAJI K, NISHIMURA N, TAKAYA H, AIHARA Y, SAWADA Y, SATO S, SEKI K, MITORO A, YAMAO J, YOSHIJI H. Predictive parameter of tolvaptan effectiveness in cirrhotic ascites. Hep. Res., 2017, $47:$ 854-61.

12. SAKAIDA I, TERAI S, NAKAJIMA K, SHIBASAKI Y, TACHIKAWA S, TSUBOUCHI H. Predictive factors of the pharmacological action of tolvaptan in patients with liver cirrhosis: a post hoc analysis. J. Gastroenterol., 2017, 52 : 229-36.

13. UOJIMA H, KINBARA T, HIDAKA H, SUNG JH, ICHIDA M, TOKORO S, MASUDA S, TAKIZAWA S, SASAKI A, KOIZUMI K, EGASHIRA H, KAKO M. Close correlation between urinary sodium excretion and response to tolvaptan in liver cirrhosis patients with ascites. Hep. Res., 2017, 47 : E14-e21.

14. MIYAAKI H, NAKAMURA Y, ICHIKAWA T, TAURA N, MIUMA S, SHIBATA H, HONDA T, NAKAO K. Predictive value of the efficacy of tolvaptan in liver cirrhosis patients using free water clearance. Biomed. Rep., $2015,3: 884-86$.

15. BELLOS I, KONTZOGLOU K, PSYRRI A, PERGIALIOTIS V. Tolvaptan Response Improves Overall Survival in Patients with Refractory Ascites: A Meta-Analysis. Dig. Dis., $2019:$ 1-9.

16. NAMBA M, HIRAMATSU A, AIKATA H, KODAMA K, UCHIKAWA S, OHYA K, MORIO K, FUJINO H, NAKAHARA T, MURAKAMI E, YAMAUCHI M, KAWAOKA T, TSUGE M, IMAMURA M, CHAYAMA $\mathrm{K}$. Management of refractory ascites attenuates muscle mass reduction and improves survival in patients with decompensated cirrhosis. J. Gastroenterol, 2020, $55: 217-26$

17. HIRAMINE Y, UTO H, MAWATARI S, KANMURA S, IMAMURA Y HIWAKI T, SAISHOJI A, YADA T, INADA Y, SAKAMOTO H, HIGASHI H, KUBOZONO O, MAENOHARA S, IDO A. Effect of tolvaptan on the prognosis of patients with hepatic ascites. Hep. Res., 2019, 49 : 765-77.

18. BELLOS I, KONTZOGLOU K, PERREA DN. Predictors of tolvaptan short-term response in patients with refractory ascites: A meta-analysis. $J$. Gastroenterol. Hepatol., 2020, 35 : 182-91.

19. OHKI T, SATO K, YAMADA T, YAMAGAMI M, ITO D, KAWANISHI K, KOJIMA K, SEKI M, TODA N, TAGAWA K. Efficacy of tolvaptan in patients with refractory ascites in a clinical setting. World J. Hepatol., 2015, 7 : 1685-93.

20. EASL Clinical Practice Guidelines for the management of patients with decompensated cirrhosis. J. Hepatol., 2018, 69 : 406-60.

21. RUNYON BA. Introduction to the revised American Association for the Study of Liver Diseases Practice Guideline management of adult patients with ascites due to cirrhosis 2012. Hepatology, 2013, 57 : 1651-3.

22. CONN HO, LEEVY CM, VLAHCEVIC ZR, RODGERS JB, MADDREY WC, SEEFF L, LEVY LL. Comparison of lactulose and neomycin in the treatment of chronic portal-systemic encephalopathy. A double blind controlled trial. Gastroenterology, 1977, 72 : 573-83.
23. WEISSENBORN K. Hepatic Encephalopathy: Definition, Clinical Grading and Diagnostic Principles. Drugs, 2019, 79 : 5-9.

24. SAKAIDA I, YANASE M, KOBAYASHI Y, YASUTAKE T, OKADA M, OKITA K. The pharmacokinetics and pharmacodynamics of tolvaptan in patients with liver cirrhosis with insufficient response to conventional diuretics: a multicentre, double-blind, parallel-group, phase III study. J. Int. Med. Res., 2012, 40 : 2381-93.

25. FUKUI H, SAITO H, UENO Y, UTO H, OBARA K, SAKAIDA I, SHIBUYA A, SEIKE M, NAGOSHI S, SEGAWA M, TSUBOUCHI H, MORIWAKI H, KATO A, HASHIMOTO E, MICHITAKA K, MURAWAKI T, SUGANO K, WATANABE M, SHIMOSEGAWA T. Evidence-based clinical practice guidelines for liver cirrhosis 2015. J. Gastroenterol., 2016, 51 : 629-50.

26. AUSTIN PC. Propensity-score matching in the cardiovascular surgery literature from 2004 to 2006: a systematic review and suggestions for improvement. J. Thorac. Cardiovasc. Surg., 2007, 134 : 1128-35.

27. AUSTIN PC. An Introduction to Propensity Score Methods for Reducing the Effects of Confounding in Observational Studies. Multivariate Behav. Res., 2011, $46:$ 399-424.

28. PROGRAM CTE. Common Terminology Criteria for Adverse Events (CTCAE) v5.0.Available from : https://ctep.cancer.gov/protocolDevelopment/ electronic applications/ctc.htm\#ctc 50 .

29. DAHL E, GLUUD LL, KIMER N, KRAG A. Meta-analysis: the safety and efficacy of vaptans (tolvaptan, satavaptan and lixivaptan) in cirrhosis with ascites or hyponatraemia. Aliment. Pharmacol. Ther., 2012, 36 : 619-26.

30. YAN L, XIE F, LU J, NI Q, SHI C, TANG C, YANG J. The treatment of vasopressin $\mathrm{V} 2$-receptor antagonists in cirrhosis patients with ascites : a metaanalysis of randomized controlled trials. BMC Gastroenterol., 2015, 15 : 65.

31. CHISHINA H, HAGIWARA S, NISHIDA N, UESHIMA K, SAKURAI T, IDA H, MINAMI Y, TAKITA M, KONO M, MINAMI T, IWANISHI M, UMEHARA Y, WATANABE T, KOMEDA Y, ARIZUMI T, KUDO M. Clinical Factors Predicting the Effect of Tolvaptan for Refractory Ascites in Patients with Decompensated Liver Cirrhosis. Dig. Dis., 2016, 34 : 659-64.

32. ZACCHERINI G, BERNARDI M. The role and indications of albumin in advanced liver disease. Acta Gastroenterol, Belg., 2019, 82 : 301-08.

33. OKITA K, SAKAIDA I, OKADA M, KANEKO A, CHAYAMA K, KATO M, SATA M, YOSHIHARA H, ONO N, MURAWAKI Y. A multicenter, openlabel, dose-ranging study to exploratively evaluate the efficacy, safety, and dose-response of tolvaptan in patients with decompensated liver cirrhosis. $J$. Gastroenterol., 2010, 45 : 979-87.

34. SAKAIDA I, NAKAJIMA K, OKITA K, HORI M, IZUMI T, SAKURAI M, SHIBASAKI Y, TACHIKAWA S, TSUBOUCHI H, OKA H, KOBAYASHI H. Can serum albumin level affect the pharmacological action of tolvaptan in patients with liver cirrhosis? A post hoc analysis of previous clinical trials in Japan. J. Gastroenterol, 2015, 50 : 1047-53.

35. CARACENI P, RIGGIO O, ANGELI P, ALESSANDRIA C, NERI S, FOSCHI FG, LEVANTESI F, AIROLDI A, BOCCIA S, SVEGLIATIBARONI G, FAGIUOLI S, ROMANELLI RG, COZZOLONGO R, DI MARCO V, SANGIOVANNI V, MORISCO F, TONIUTTO P, TORTORA A, DE MARCO R, ANGELICO M, CACCIOLA I, ELIA G, FEDERICO A, MASSIRONI S, GUARISCO R, GALIOTO A, BALLARDINI G, RENDINA M, NARDELLI S, PIANO S, ELIA C, PRESTIANNI L, CAPPA FM, CESARINI L, SIMONE L, PASQUALE C, CAVALLIN M, ANDREALLI A, FIDONE F, RUGGERI M, RONCADORI A, BALDASSARRE M, TUFONI M, ZACCHERINI G, BERNARDI M. Long-term albumin administration in decompensated cirrhosis (ANSWER): an open-label randomised trial. Lancet, 2018, $391:$ 2417-29. 